\title{
Type 2 Diabetes Current and Future Medications: A Short Review Jahangir MA ${ }^{1}$, Imam $S S^{* 1}$, Kazmi $I^{2}$, Muheem $A^{3}$

\begin{abstract}
${ }^{1}$ Department of Pharmaceutics, Glocal School of Pharmacy, Glocal University, Saharanpur, India ${ }^{2}$ Department of Pharmacology, Glocal School of Pharmacy, Glocal University, Saharanpur, India ${ }^{3}$ Department of Pharmaceutics, Faculty of Pharmacy, Jamia Hamdard, New Delhi, India
\end{abstract}

*Corresponding author: Imam SS, Department of Pharmaceutics, Glocal School of Pharmacy, Glocal University, Saharanpur, India, E-mail: sarimimam@ gmail.com

Received: February 05, 2017; Revised: February 25, 2017; Published: March 01, 2017

Copyright: (C2017 Imam SS, et al. This is an open-access article distributed under the terms of the Creative Commons Attribution License, which permits unrestricted use, distribution, and reproduction in any medium, provided the original author and source are credited. The article has been previewed and authenticated by the Authors before sending the publication for print. The Journal, Editor and the Editorial Board are not entitled or liable to either justify or responsible for inaccurate and misleading data if any. It is the sole responsibility of the Author concerned.

Citation: Jahangir MA, Imam SS, Kazmi I, et al. Type 2 Diabetes Current and Future Medications: A Short Review. Int J Pharm Pharmacol 2017; 1: 101. doi: 10.31531/2581-3080.1000101

\begin{abstract}
Diabetes Mellitus (DM) is a complex set of disease. It is basically a metabolic disorder in which body is unable to make enough insulin or it is not able to use insulin effectively or in some instances both. According to global report on diabetes released by World Health Organization, Geneva 422 million people suffers from diabetes in 2014. The number is expected to increase to 552 million by 2030. A number of researches are going on around the globe by pharmaceutical companies to exploit the huge market it provides. This short review covers the brief basics of DM and its classification medication. This review mainly focus on type 2 diabetes discussing the new classification of medication available in the market as well as the approved antidiabetic drugs for type 2 diabetes by USFDA after 2010 and the pipeline antidiabetic drugs under clinical trials. This short review article has been prepared reviewing data available from PubMed, National Institute of Health, USFDA, clinicaltrials.gov and other related sites.
\end{abstract}

Keywords: Diabetes Mellitus, Type 2 diabetes, USFDA

\section{Introduction}

Diabetes is a complex set of diseases. Most commonly people with diabetes suffers from high blood sugar/glucose which in scientific term known as hyperglycaemia. It is a metabolic disorder in which body is unable to make enough insulin or it is not able to use insulin effectively or both [1]. There are broadly two categories of diabetes- type 1 diabetes and type 2 diabetes. There is another type of diabetes namely gestational diabetes which usually develops during pregnancy. Type 1 diabetes is caused by lack of insulin due to destruction of insulin producing beta cells (Islets of Langerhans) in the pancreas [1]. Thus, it is also known as insulin dependent diabetes mellitus. Type 1 diabetes is an autoimmune disease which usually occurs in children and young adults and thus it is sometimes also referred to as Juvenile diabetes [1]. The main causes of type 1 diabetes are - autoimmune destruction of Beta cells, genetic susceptibility, environmental factors, viruses and infections. 
Type 2 diabetes is the commonest form of diabetes. It is caused by a combination of factors including insulin resistance, in which the body is unable to use the insulin effectively. Type 2 diabetes develops when the body is unable to compensate for the impaired ability to use insulin by producing enough insulin. The main causes of type 2 diabetes are- genetic susceptibility, obesity and physical inactivity, insulin resistance, abnormal glucose production by the liver, beta cell dysfunction [1].

According to global report on diabetes released by World Health Organization, Geneva 422 million people suffers from diabetes in 2014 (http://www.who.int/mediacentre/factsheets/en) [2]. The number is expected to increase to 552 million by 2030 [3]. The numbers suggest that $80 \%$ of the people with DM are living in low or middle income countries [3]. A number of researches are going on around the globe by pharmaceutical companies to exploit the huge market it provides.

\section{Conventional Medicines and Future Drugs}

No cure has yet been found for the disease; however, treatment modalities include lifestyle modifications, treatment of obesity, oral hypoglycemic agents, and insulin sensitizers like metformin, a biguanide that reduces insulin resistance, is still the recommended first line medication especially for obese patients. Other effective medications include non-sulfonylurea, thiazolidinediones, alpha glucosidase inhibitor, and insulin. The classification of conventional anti-diabetic medication and their mechanism of actions (www.drugs.com) [4] are listed in Table 1. Recent research into the pathophysiology of type $2 \mathrm{DM}$ has led to the introduction of new medications like glucagonlike peptide 1 analogous, dipeptidyl peptidaseIV inhibitors, inhibitors of the sodium-glucose cotransporter-2 and 11ß-hydroxysteroid dehydrogenase 1 , insulin-releasing glucokinase activators and pancreatic-G-protein-coupled fatty-acid-receptor agonists, glucagon-receptor antagonists, metabolic inhibitors of hepatic glucose output and quick-release bromocriptine. Inhaled insulin was licensed for use in 2006 but has been withdrawn from the market because of low patronage [3].

\section{Dipeptidyl Peptidase-4 Inhibitors}

Imam SS, et al. Int J Pharm Pharmacol
Dipeptidyl Peptidase-4 Inhibitors (DPP-4) or in short gliptins falls in the newest class of drugs used for type 2 diabetes indications. DPP-4 is actually an enzyme which inhibits glucagon like peptide-1 or GLP-1. The function of GLP1 is to trigger the $\beta$-cells of pancreas to release insulin. DPP-4 inhibitors stop DPP-4 enzyme from destroying GLP-1, which in turns stimulates $\beta$-cells of pancreas to release more insulin. Sitagliptin is an approved drug from FDA of this class. It is either used as a sole drug or in combination with metformin for the management of type 2 diabetes.

\section{GLP-1 Mimetics (Incretin Mimetics)}

GLP-1 is a hormone which is released from the digestive tract at the time of digestion. The function of GLP-1 is to stimulate the $\beta$-cells of pancreas to release more insulin. Since, a DPP4 enzyme destroys GLP-1. The GLP-1 mimetic mimics the function of GLP-1 hormone and stimulates pancreas to release insulin. The GLP-1 synthetic mimetic agent is not recognized by DPP-4 enzyme as the same naturally occurring GLP-1 hormone. Exenatide is an injectable medication approved by FDA for the management of type 2 diabetes [5]. Liraglutide is another drug approved in this class.

\section{Amylin Analog}

Amylin is a hormone, which reduces glucagon. Glucagon is another hormone which causes the body to release or produce glucose. Thus, amylin analog indirectly influences the glucose level in the blood by reducing the glucagon level in the body [5]. Pramlinitide is an injectable medication approved by FDA for the management of type 2 diabetes.

\section{Rimonabant}

Endocannabinoid system (ECS) is a newly found physiological endocrine system that plays a key role in appetite and energy metabolism both in the brain as well as in the adipose tissue [6-8]. In the animal studies, it has been found that blocking ECS has led to weight loss and improved insulin sensitivity. By blocking CB1 receptors, rimonabant has been shown to reduce weight by suppressing appetite and by modifying glucose and fat metabolism [8-10]. Rimonabant has undergone 
phase 3 trials and is licensed for use in patients who have a BMI $>30 \mathrm{~kg} / \mathrm{m}^{2}$ or BMI $>27 \mathrm{~kg} / \mathrm{m}^{2}$ with an additional risk factor such as dyslipidaemia or diabetes [11].

\section{New Medications and Pipeline Drugs}

Upon reviewing USFDA data of approved drugs for type 2 diabetes since 2010, it was found that there are about fifteen new medicines or new combination of old medicines for type 2 diabetes approved. The maximum approval of type 2 medication was for Boehringer Ingelheim with three approvals, while Eli Lilly got two USFDA approvals for type 2 diabetes indication since 2010 . The list is tabulated in Table 2 [12].

There a number of new medicinal entities undergoing clinical trials and is under the pipeline of many major pharmaceutical industries. Upon short reviewing of type 2 diabetes medications in clinicaltrials.gov it was found that GlaxoSmithKline has two drugs namely Denagliptin and GSK523338 both in their phase 3 trials, AstraZeneca have Pramlintide Acetate which is in phase 4. Other medication which is in their phase 4 trials are Cholecalciferol, and Iobitridol which belongs to Tufts Medical Center and Merck Sharp \& Dohme Corp. respectively. The list is tabulated in Table 3 [13].

\section{Conclusion}

Diabetes is complex metabolic disorder, which influences the whole metabolic function of the patient. A person suffering from diabetes may also develop some other disease like hypertension, cataract, kidney dysfunction etc. The number of persons suffering from diabetes is increasing day by day and is expected to influence 552 million people in the world by 2030. Most of the people suffering from diabetes either belongs to low or middle income countries. Diabetes provides a huge market for the pharmaceutical industry. A number of new medicines have been approved by USFDA since 2010. The major pharmaceutical companies are sponsoring clinical trials and are having a number of new medicinal entities or new combination of old Imam SS, et al. Int J Pharm Pharmacol medicinal strategies for type 2 diabetes in their pipeline drug. But the dilemma with this disease is that no possible cure is still reported.

\section{Acknowledgement}

The authors would like to acknowledge the support of senior professors whose continuous guidance helped us in shaping the article.

\section{Conflict of Interest}

The authors declare no conflict of interest.

\section{References}

1. https://www.niddk.nih.gov/healthinformation/diabetes/causes accessed on 20/11/2016.

2. http://www.who.int/mediacentre/factshe ets/en/ accessed on 24/02/2017.

3. Olokoba AB, Obateru OA, Olokoba LB. Type 2 diabetes mellitus: a review of current trends. Oman Med J 2012; 4 : 269-273.

4. https://www.drugs.com/drugclass/antidiabetic-agents.html accessed on $25 / 02 / 2017$.

5. http://www.endocrineweb.com/conditio ns/type-2-diabetes/new-medicationstype-2-diabetes accessed on 26/11/2016.

6. Cota D, Marsicano G, Tschop M, Grubler Y, et al. The endogenous cannabinoid system affects energy balance via central orexigenic drive and peripheral lipo-genesis. J Clin Invest 2003; 112: 423-431.

7. Di Marzo V, Matias I. Endocannabinoid control of food intake and energy balance. Nat Neurosci 2005; 8: 585-58.

8. Wynne K, Stanley S, McGowan B, et al. Appetite control. J Endocrinol 2005; 184: 291-318.

9. Jbilo O, Ravinet-Trillou C, Arnone M. The CB1 receptor antagonist rimonabant reverses the diet-induced obesity phenotype through the regulation of lipolysis and energy 
balance. FASEB J 2005; 19 :15671569.

10. Rinaldi-Carmona M, Barth F, Heaulme $M$, et al. SR141716A, a potent and selective antagonist of the brain cannabinoid receptor. FEBS Lett 1994; 350: 240-244.

11. Srinivasan BT, Jarvis J,Khunti K, et al. Recent advances in the management of type 2 diabetes mellitus: a review. Postgrad Med J 2008; 84 :524-531.

12. http://www.accessdata.fda.gov/scripts/c der/daf/index.cfm?event=reportsSearch. process accessed on 21/11/2016.

13. https://clinicaltrials.gov/ct2/home accessed on 23/11/2016.

Table 1: Classification and mechanism of action of conventional anti-diabetic drug

\begin{tabular}{|c|c|c|}
\hline Class of Anti-diabetic drug & Mechanism of Action & Examples \\
\hline Alpha-glucosidase inhibitors & $\begin{array}{l}\text { Competitive and reversible } \\
\text { inhibition of Alpha-glucosidase } \\
\text { enzyme }\end{array}$ & Acarbose, Miglitol \\
\hline Meglitinides & $\begin{array}{l}\text { Stimulates the pancreas to } \\
\text { release insulin in response to } \\
\text { meal }\end{array}$ & Repaglinide, Nateglinide \\
\hline Non-sulfonylureas (biguanides) & $\begin{array}{l}\text { Inhibits the amount of glucose } \\
\text { produced by liver, increased } \\
\text { insulin receptor binding, } \\
\text { stimulates tissue uptake of } \\
\text { glucose }\end{array}$ & Metformin \\
\hline $\begin{array}{l}\text { Sodium-Glucose transporter-2 } \\
\text { (SGLT-2) }\end{array}$ & $\begin{array}{l}\text { Lowers renal glucose threshold, } \\
\text { results in increased amount of } \\
\text { glucose excretion from urine. }\end{array}$ & $\begin{array}{l}\text { Canagliflozin, Empagliflozin, } \\
\text { Dapagliflozin }\end{array}$ \\
\hline Sulfonylureas & $\begin{array}{l}\text { Stimulates the pancreas to } \\
\text { release more insulin }\end{array}$ & $\begin{array}{l}\text { Chlorpropamide, glimepiride, } \\
\text { Glyburide, Glipizide, } \\
\text { Tolazamide, Tolbutamide }\end{array}$ \\
\hline Thiazolidinediones (glitazones) & $\begin{array}{l}\text { Acts as agonists for peroxisome } \\
\text { proliferator-activated receptors } \\
\text { gamma (PPARgamma), } \\
\text { behaving as insulin sensitizer }\end{array}$ & Rosiglitazone, Pioglitazone \\
\hline Insulin & $\begin{array}{l}\text { Polypeptide hormone, regulates } \\
\text { the amount of glucose in the } \\
\text { blood }\end{array}$ & $\begin{array}{l}\text { Insulin regular, Insulin aspart, } \\
\text { Insulin lispro, Insulin isophane, } \\
\text { Insulin regular, insulin glargine, } \\
\text { Insulin detemir, Insulin zinc } \\
\text { extended, insulin degludec }\end{array}$ \\
\hline
\end{tabular}


Table 2: List of drugs approved by USFDA after 2010 for type 2 diabetes

\begin{tabular}{|c|c|c|c|}
\hline Drug & Brand Name & Company & Approved Year \\
\hline Lixisenatide & Adlyxin & Sanofi Aventis & 2016 \\
\hline $\begin{array}{l}\text { Empagliflozin }+ \text { Metformin } \\
\text { Hydrochloride }\end{array}$ & Synjardy & BoehringerIngelheim & 2015 \\
\hline Insulin Degludec Injection & Tresiba & Novo Nordisk & 2015 \\
\hline Dapagliflozin & Farxiga & Bristol-Myers Squibb & 2014 \\
\hline Empagliflozin & Jardiance & Boehringer Ingelheim & 2014 \\
\hline Albiglutide & Tanzeum & GlaxoSmithKline & 2014 \\
\hline Dulaglutide & Trulicity & Eli Lilly & 2014 \\
\hline $\begin{array}{l}\text { Dapagliflozin } \\
\text { Hydrochloride }\end{array}$ & Xigduo XR & AstraZeneca & 2014 \\
\hline Canagliflozin & Invokana & Janssen Pharmaceuticals & 2013 \\
\hline Alogliptin & Nesina & Takeda & 2013 \\
\hline $\begin{array}{llll}\text { Exenatide } & \text { XR for } & \text { Injection } \\
\text { Suspension } & & & \end{array}$ & Bydureon & Amylin & 2012 \\
\hline $\begin{array}{ll}\text { Linagliptin+ } & \text { Metformin } \\
\text { Hydrochloride } & \\
\end{array}$ & Jentadueto & Eli Lilly & 2012 \\
\hline Sitagliptin And Simvastatin & Juvisync & Merck & 2011 \\
\hline Linagliptin & Tradjenta & Boehringer Ingelheim & 2011 \\
\hline Liraglutide & Victoza & Novo Nordisk & 2010 \\
\hline
\end{tabular}

Table 3: List of some pipeline anti-diabetic drugs under clinical trials

\begin{tabular}{|l|l|l|}
\hline \multicolumn{1}{|c|}{ Drug } & \multicolumn{1}{c|}{ Sponsor } & \multicolumn{1}{c|}{ Phase } \\
\hline MBX-102 & Cymabay Therapeutics, Inc. & Phase 3 \\
\hline Denagliptin (GW823093) & GlaxoSmithKline & Phase 3 \\
\hline Cholecalciferol & Tufts Medical Center & Phase 4 \\
\hline Pramlintide Acetate & AstraZeneca & Phase 4 \\
\hline ETC-1002 & Esperion Therapeutics 2 \\
\hline DS-8500a & Daiichi Sankyo Co., Ltd. & Phase 2 \\
\hline ASP1941 & Astellas Pharma Korea, Inc. & Phase 3 \\
\hline GSK523338 & GlaxoSmithKline & Phase 3 \\
\hline Iobitridol & Guerbet & Phase 4 \\
\hline Omarigliptin & Merck Sharp \& Dohme Corp. & Phase 1 \\
\hline
\end{tabular}


This manuscript was peer-reviewed

Mode of Review: Single-blinded

\section{Editor: Chee Chean Dang}

International Journal of Pharmaceutics and Pharmacology is an open access, peer reviewed journal published by Edwiser International.

Submit your valuable manuscript at-

editor.ijpp@edwiserinternational.com

submit.manuscript@edwiserinternational.com

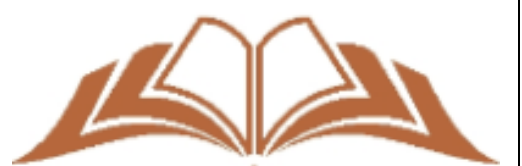

EDW $\mathrm{D}$ S E R

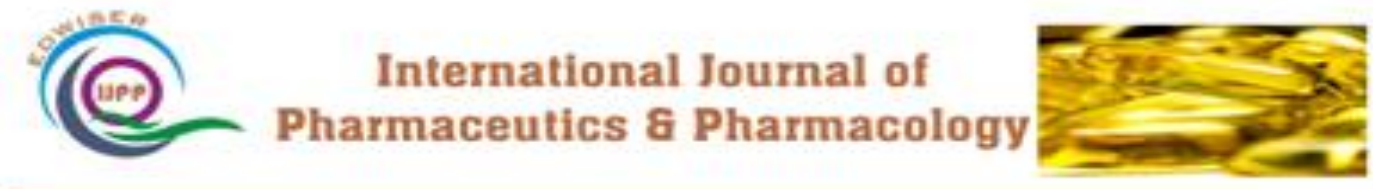

International Journal of General Medicine \& Surgery
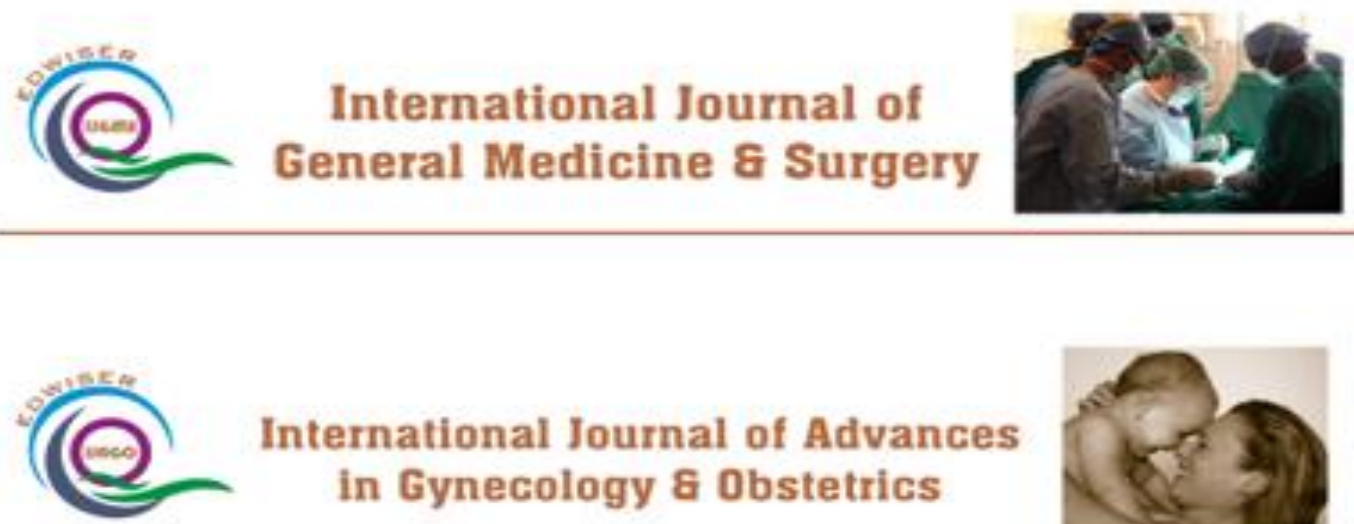

International Journal of Advances

in Gynecology \& Obstetrics
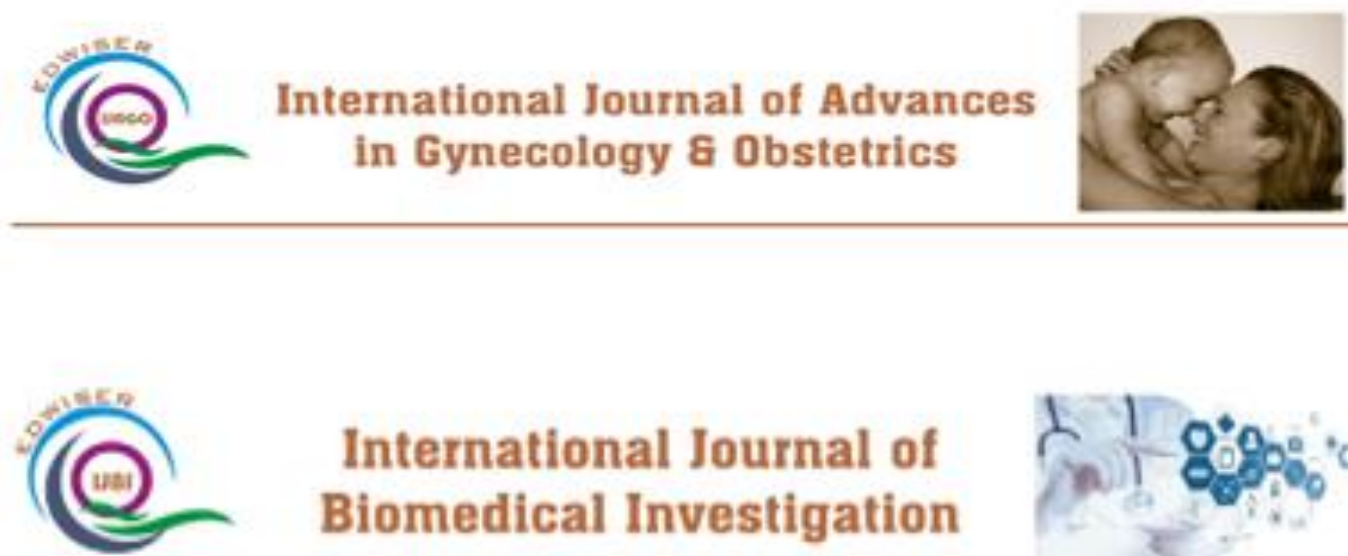

International Journal of Biomedical Investigation
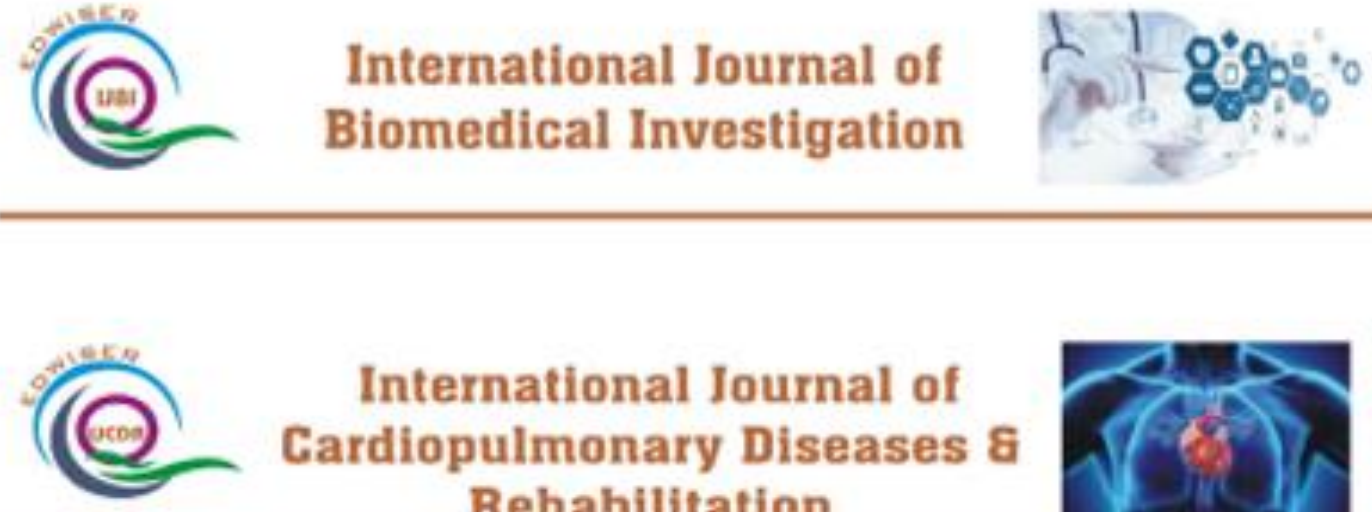

\section{International Journal of Cardiopulmonary Diseases \& Rehabilitation}

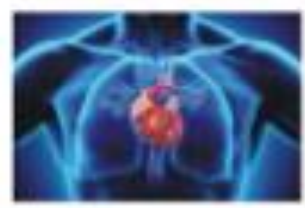

